\title{
Acute MRI changes in opiate-induced toxic leukoencephalopathy
}

\author{
Hoameng Ung 두, Robert Hess, Fanny Du
}

Department of Neurosciences, University of California San Diego, San Diego, California, USA

\section{Correspondence to Hoameng Ung; hoameng.ung@gmail.com}

Accepted 5 March 2021

\section{DESCRIPTION}

A 35-year-old woman with a history of substance abuse and a seizure disorder presented to the emergency department with altered mental status. According to her family, she was behaving oddly for the past several days, including standing and staring throughout the day, not speaking and resisting taking medications. The family had not witnessed this behaviour in the past. They did endorse a substance abuse history, including opiates, for which she had previously been on methadone. On examination, the patient was persistently hypertensive and tachycardic, aroused to voice, but was otherwise nonverbal. She followed minimal simple commands and had diffusely slowed movements. An MRI brain was performed on day 1 (figure 1A) that was unremarkable with the exception of a non-specific T2 hyperintensity on the $\mathrm{L}$ posterior centrum semiovale of unclear significance. She had no prior MR imaging for comparison. Prolonged electroencephalogram captured a right posterior quadrant seizure without clear clinical correlate, and at this time it was presumed that her abnormal behaviour was secondary to intermittent seizure activity. The patient's home levetiracetam dose was increased from $1000 \mathrm{mg}$ twice a day to $1500 \mathrm{mg}$ twice a day. However, the following day, the patient then developed arrhythmic, distractible whole body shaking spells without electrographic correlate suggesting a mixed epileptic and non-epileptic

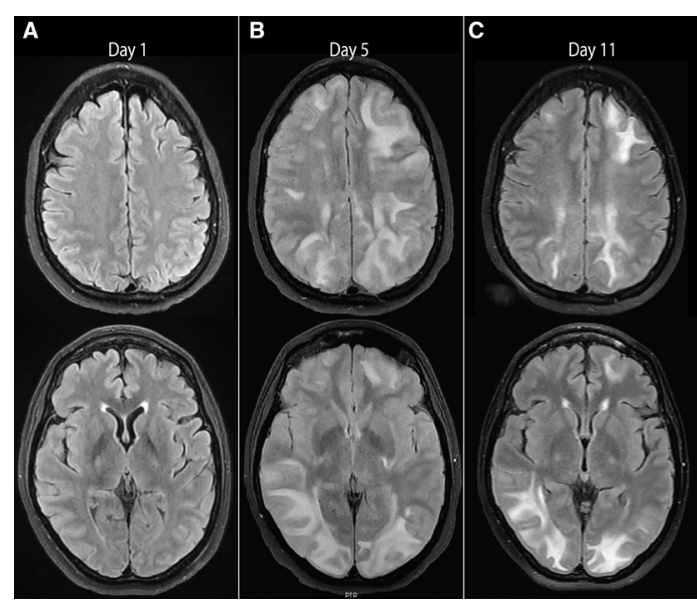

Figure 1 Axial T2 flair MRI slices on days 1 (A), 5 (B) and 11 (C) of presentation. Non-specific T2 hyperintensity seen in the left centrum semiovale on day 1 (A). By day 5 (B), worsening of diffuse white matter hyperintensities in bilateral cerebral hemispheres that continued to evolve. On day 11 (C), white matter hyperintensities are much improved, corresponding with the patient's clinical improvement.

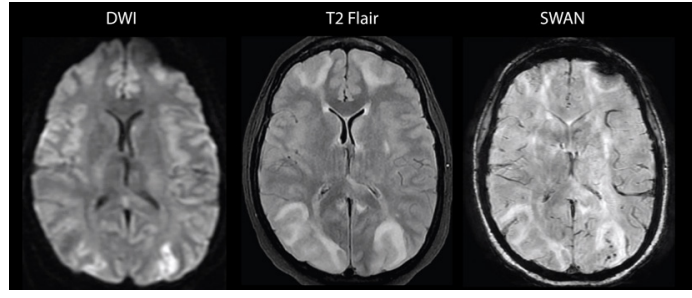

Figure 2 Diffusion-weighted imaging, T2 flair, and susceptibility weighting angiography sequences on day 5 of presentation. Evolving diffusion restriction with hyperintensities on $\mathrm{T} 2$ flair and petechial haemorrhages on susceptibility weighted angiography. These findings were not present on day 1 .

disorder. On days 4-5 since admission, her examination further deteriorated, now with spasticity in the upper extremities, a left Babinski sign, and a retarded catatonic-like state without response to noxious stimuli. A repeat MRI brain obtained at this time (figure 1B) showed interval development of diffuse T2 white matter hyperintensities throughout both cerebral hemispheres with patchy regions of gyriform thickening and oedema. Additionally, there was interval worsening of diffusion restriction and multifocal petechial haemorrhage throughout the cortex of both cerebral hemispheres (figure 2). This was concerning for a toxic leukoencephalopathy most likely secondary to substance abuse. ${ }^{1}$ The patient was started on empiric antioxidants (Coenzyme Q10, Vitamin E, Vitamin C) due to possible mechanism of mitochondrial dysfunction. Concurrently, the patient was treated briefly with empiric acyclovir, while the infectious workup was pending and ultimately

Learning points

- Toxic leukoencephalopathy can occur from snorting oxycodone with delayed onset and continued progression, despite discontinuation of the substance.

- Clinical presentation depends on the degree of white matter disease and consists of abnormal vital signs with tachycardia and hypertension, neurobehavioural deficits that include inattention, pseudobulbar affect and apathy before development of tremors and spasticity on examination.

- Our findings suggest that the classic neuroimaging findings may lag behind clinical symptoms, and that the changes seen on MRI rapidly change over the course of 5-10 days. 
returned negative. An inflammatory or demyelinating process was also considered, however, there was no additional evidence on serum and cerebrospinal fluid studies or MRIs of the cervical spine to support this. Over the next week, the patient gradually began speaking in stunted sentences with a flat affect and confirmed snorting crushed oxycodone and benzodiazepine tablets 3 weeks prior to presentation. She denied intravenous drug use or inhaling heroin vapours. While toxic leukoencephalopathy from substance abuse is more commonly associated with inhaling heroin vapours, also called 'chasing the dragon', it has also been seen with use of other opioids and administration methods. ${ }^{2}$ Finally, a third MRI of the brain obtained 11 days after presentation showed interval improvement of the diffuse T2 hyperintensities correlating with her improving examination. The following images demonstrate the progressive evolution of the patient's brain MRI, consistent with toxic leukoencephalopathy most likely secondary to snorting crushed opiates.
Contributors HU wrote the case report and prepared the images. RH helped revise the report. FD identified the case and helped with revisions. All authors were involved in patient's clinical care.

Funding The authors have not declared a specific grant for this research from any funding agency in the public, commercial or not-for-profit sectors.

Competing interests None declared.

Patient consent for publication Obtained.

Provenance and peer review Not commissioned; externally peer reviewed.

\section{ORCID iD}

Hoameng Ung http://orcid.org/0000-0003-2088-4889

\section{REFERENCES}

1 Filley CM, Kleinschmidt-DeMasters BK. Toxic leukoencephalopathy. N Engl J Med 2001;345:425-32.

2 Wheaton T, Toll BJ, Breznak K, et al. Opioid-Induced toxic leukoencephalopathy: a case report and review of the literature. Heliyon 2019;5:e03005.

Copyright 2021 BMJ Publishing Group. All rights reserved. For permission to reuse any of this content visit

https://www.bmj.com/company/products-services/rights-and-licensing/permissions/

BMJ Case Report Fellows may re-use this article for personal use and teaching without any further permission.

Become a Fellow of BMJ Case Reports today and you can:

- Submit as many cases as you like

- Enjoy fast sympathetic peer review and rapid publication of accepted articles

- Access all the published articles

- Re-use any of the published material for personal use and teaching without further permission

\section{Customer Service}

If you have any further queries about your subscription, please contact our customer services team on +44 (0) 2071111105 or via email at support@bmj.com.

Visit casereports.bmj.com for more articles like this and to become a Fellow 